\title{
Comprehensiveness and humanization of nursing care management in the Intensive Care Unit*
}

\author{
Integralidade e humanização na gestão do cuidado de \\ enfermagem na Unidade de Terapia Intensiva \\ Integralidad y humanización en la gestión del cuidado de \\ enfermería en la Unidad de Cuidados Intensivos
}

Adriane Calvetti de Medeiros ${ }^{1}$, Hedi Crecencia Heckler de Siqueira ${ }^{1}$, Claudia Zamberlan², Diana Cecagno ${ }^{3}$, Simone dos Santos Nunes ${ }^{1}$, Mara Regina Bergmann Thurow ${ }^{1}$

How to cite this article:

Medeiros AC, Siqueira HCH, Zamberlan C, Cecagno D, Nunes SS, Thurow MRB. Comprehensiveness and humanization of nursing care management in the Intensive Care Unit. Rev Esc Enferm USP. 2016;50(5):816-822. DOI: http://dx.doi.org/10.1590/S0080-623420160000600015

*Extracted from the theses "Gestão do Cuidado de Enfermagem na UTI: configuração ecossistêmica com base teórico-filosófica e organizativa nas políticas públicas”,

Programa de Pós-graduação em Enfermagem, Universidade Federal de Rio Grande, 2013.

${ }^{1}$ Universidade Federal do Rio Grande, Escola de Enfermagem, Rio Grande, RS, Brazil.

${ }^{2}$ Centro Universitário Franciscano, Santa Maria, RS, Brazil.

${ }^{3}$ Universidade Federal de Pelotas, Faculdade de Enfermagem, Pelotas, RS, Brazil.

\begin{abstract}
Objective: Identifying the elements that promote comprehensiveness and humanization of nursing care management in the Intensive Care Unit, with an ecosystemic approach. Method: A documentary qualitative study. The method of documentary analysis was used for data analysis. Results: Four pre-established categories were identified Technical; Organizational; Technological; and Humanizing Dimensions. Data resulted in forming two sub-categories that integrate the humanizing dimension category, namely 'Comprehensiveness in healthcare actions' and 'Integrating processes and promoters of humanization,' bringing forth implications and challenges in forms of managing health work processes, enabling organizational, structural and managerial changes to the provided healthcare. Conclusion: It was considered that all structural elements in managing nursing care with a focus on the needs of users should be in line with public policies and the principles of comprehensiveness and humanization, thus possessing strong potential for transforming health practices.
\end{abstract}

\section{DESCRIPTORS}

Health Management; Nursing Care; Humanization of Assistance; Intensive Care Unit; Integrality in Health; Health Public Policy. 


\section{INTRODUCTION}

Comprehensiveness as a doctrinarian, constitutional and fundamental principle of the Unified Health System (SUS), is constituted in the processes of construction, implementation and consolidation of a healthcare model that has its foundation and procedures structured in the promotion, prevention, treatment and rehabilitation of health. The objective to be achieved is the production of health with social value and citizenship. Thus, comprehensiveness composes the central element in the configuration of a health model that effectively incorporates the basic guidelines of the SUS, meaning to decentralize actions, comprehensive healthcare, promoting equity and social participation ${ }^{(1)}$.

According to this line of thought, in order to enhance and produce changes in health production, multiple instances of the SUS should be interrelated in Primary Healthcare of both middle and high complexity ${ }^{(2)}$. Promoting changes implies reflecting on the different possibilities of approaches to the different realities of health services ${ }^{(3)}$. To this end, it is necessary to overcome the biomedical model based on curative and fragmented practices, and to provide quality, resolute, humanized and comprehensive healthcare to all users at all levels of healthcare, including hospital care. It is understood that the Health Policies in Brazil were regulated to support and guide healthcare practices in their complex and emerging perspectives, seeking healthcare that pervades a Cartesian/fragmented dimension, and thus enabling comprehensiveness.

Comprehensiveness in healthcare actions has implications and challenges in how to manage the health work processes, as well as expanding actions for the multiple dimensions of the human being. These need to be perceived and understood based on the interrelationships of components that comprise reality, which for health professionals enables an expanded understanding of the health-disease-care process and the need for interventions by considering the context in which the event happens ${ }^{(3-5)}$.

Reconfiguring the health-disease-care process in order to address epidemiological, biological, psychological, cultural, social and spiritual aspects of the user's problems represents a new way of thinking and acting in order to obtain solutions to emerging issues for producing care ${ }^{(5)}$. This form of thinking and acting is based on the systemic/ecosystemic theory by considering that all elements/services need to be interconnected and contextualized in order to provide care to the human being in a comprehensive and quality manner. Thus, to understand the dimensional needs of the human being and their different ways of living, we need to include healthcare actions which study the characteristics and specificities of the space in which humans live, work and develop ${ }^{(5-7)}$. Therefore, the emerging thinking is able to contribute to the (re)organization of existing health practices, qualifying the care and guiding care management in health/nursing.

In the Intensive Care Unit (ICU), nursing care management (the theme of this research) is based on the totality and specificities of the elements of this ecosystem, and is understood as a care space/environment which interrelatedly and interdependently involves technical, organizational, technological and humanizing healthcare production ${ }^{(8)}$. In order to obtain the expected results, it is necessary to understand the interrelationships between these dimensions and their interfaces in health production. This inter-relational dynamic constitutes the complexity of nursing care by the ICU user ${ }^{(6,8)}$.

In the production of care, all structural elements focused on the needs of users should be in line with the public policies and principles of comprehensive and humanized care, respecting the effective participation of different professionals involved in caring for critical users ${ }^{(9)}$. Thus, it is possible to observe a structural self-organization in health production ICUs resulting from an interrelationship of physical space, material resources and equipment, and human resources, formed by specialized multidisciplinary teams which when integrated to technological advances are able to adapt to the demand and improve the quality and safety of healthcare.

In this sense, the National Humanization Policy of Healthcare and Health Management in the SUS (HumanizaSUS) ${ }^{(10)}$ aims to contribute to improving healthcare management, since as an inclusive and resolute policy it proposes innovations in management practices and healthcare production. This implies a critical approach to enable healthcare production beyond its technical, technological and organizational components, primarily involving their political and philosophical dimensions, in which ethical, supportive and humane senses are imprinted.

Thus, in order to achieve the goal of comprehensiveness and humanization in managing nursing care in the ICU and within an ecosystemic configuration, environmental planning and developing coordinated and integrated efforts to improve healthcare and safety are necessary. However, this is also implied in meeting the needs and exceeding the expectations of users, professionals and family members. Understanding these interconnections means to encompass the diversity and circularity of relationships, interactions and interdependencies that move and preserve life in its different expressions and manifestations ${ }^{(5)}$.

Given the above of understanding the elements of space/ environment in ICUs and their interconnections and being based on public health policies and SUS principles, brings forth the possibility of providing nurses the necessary strategies to optimize nursing care management in the ICU and thereby contribute to healthcare production.

The results of the Doctoral Thesis "Gestão do Cuidado de Enfermagem na UTI: configuração ecossistêmica com base teórico-filosófica e organizativa nas politicas públicas", obtained through an analysis of official Ministry of Health $(\mathrm{MOH})$ documents which define and sustain the structural axes of the organization and operation of ICUs allowed us to identify and analyze four predetermined categories, being: Technical Dimension; Organizational Dimension; Technological Dimension and Humanizing Dimension.

As an excerpt of the thesis, this article aims to identify the elements that promote the comprehensiveness and humanization of nursing care management in the Intensive Care Unit, following an ecosystemic approach. 


\section{METHOD}

This study resulted from a documentary research process using a descriptive, exploratory, and qualitative approach. As a scientific method, documentary research is characterized by the search for information in documents that have not yet received any analytical treatment, and considers the document as a research object ${ }^{(11)}$. Thus, the description of the facts and phenomenon of a certain reality enables comprehension of the dimensions, variations and meanings that may constitute elements of analysis.

Preliminary analysis of Public Policy in Healthcare documents in relation to the ICU was carried out aimed at identifying the existence of theoretical, philosophical and organizational principles able to configure nursing care management in the ICU with an ecosystemic approach and to verify if they met inclusion criteria of being an official document/file of the MOH from 1998 to 2013, contemplated the research topic, and were available online. The choice of the period 1998 to 2013 is justified by contemplating the latest official definitions related to the subject.

From this analysis, seven official documents were identified from the Ministry of Health available on the Health Portal (Saúde Legis), with access through the Virtual Health Library of the Ministry of Health (VHL/MOH): Document 1 - Decree number 3.432, from August 12, 1998, establishing the Technical Regulation for the functioning of intensive care services and their respective classification according to the degree of complexity, service capacity and degree of risk inherent in the type of care provided $^{(12)}$; Document 2 - Resolution/RDC number 50, from February 21,2002, adopts provisions concerning Technical Regulations for planning, scheduling, preparation and evaluation of physical projects of healthcare facilities ${ }^{(13)}$; Document 3 - HumanizaSUS: National Humanization Policy, presents Humanization as a Guiding principle of Care and Management Practices for all Instances of the SUS ${ }^{(10)}$; Document 4 - MOH Decree 1071 from July 4, 2005, stipulates that the Department of Healthcare submit a draft of the National Policy of Critical Patient Care to public consultation ${ }^{(9)}$; Document 5 - Decree number 2.690, from November 5, 2009, establishes the National Policy for Technology Management in Healthcare within the context of the Unified Healthcare System (SUS)(14); Document 6 - Resolution number 7, from February 24, 2010, provides the minimum requirements for operation of Intensive Care Units in order to reduce risks to patients, visitors, professionals and the environment ${ }^{(15)}$; Document 7 - Decree number 529, from April 1, 2013, establishes the National Patient Safety Program (PNSP) ${ }^{(16)}$. All seven documents received a code, the letter $\mathrm{D}$, followed by Arabic numerals $1,2,3,4,5,6$ and 7 , according to the year of publication.

In composing the study, such documents were considered as a legal framework of Public Health Policies, as they establish definitions and guidelines for intensive care units. Thus, it was necessary to analyze the official documents and to search for theoretical, philosophical and organizational framework within its content to set the technical and operational standards of this specific area.
To analyze the content of the documents, a preliminary reading was first conducted, followed by a selective reading, aiming to capture the main highlighted concepts within the official documents. Next, the main points and their adherence and/or opposition toward the goal of this study were correlated. The actual documentary analysis was conducted in three stages: First stage: critical analysis of the document, which was based on the five dimensions described by Cellard ${ }^{(11)}: 1^{\text {st }}$ Dimension - Examination in relation to the context; $2^{\text {nd }}$ Dimension - Searching for the authors of the documents; $3^{\text {rd }}$ Dimension - Authenticity and reliability of the document; $4^{\text {th }}$ Dimension - Nature of the text; $5^{\text {th }}$ Dimension - Key concepts and internal logic of the text.

Next, the second and third stages regarding data collection were carried out, being content analysis and analysis regarding the key points of the document, respectively. For this, a research tool designed and specifically structured for this purpose was applied to each document.

Identification of the segments selected from the seven official documents of the Ministry of Health was accomplished by using the code letter $\mathrm{D}$ - it represents the document, and the Arabic numeral following the letter identifies the chronological order of the analyzed document. For example: D1 - Decree number 3432 from August 12, 1998.

Data were recorded in Analysis Units and then grouped into categories, enabling the documentary analysis and, as a result, its interpretation.

This article will present the results and discussion of the two sub-categories that emerged from the Humanizing Dimension category: 'Comprehensiveness in healthcare actions' and 'Integrating processes and promoters of humanization.'

\section{RESULTS}

The humanizing dimension has the creation of working spaces/environments as its structural base which enhance the daily practice of professionals/workers, with emphasis on relational technologies such as listening, reception, dialogue and negotiation for healthcare production and management ${ }^{(8)}$.

\section{COMPREHENSIVENESS IN HEALTHCARE ACTIONS}

From the segments present in the $\mathrm{MOH}$ documents, under the ecosystemic perspective comprehensiveness in healthcare actions is inter-related to the elements that structure and aggregate organization of the work process, management, planning and construction of new knowledge and health practices, in accordance with the following statement:

(...) the development of a National Policy of Critical Patient Care based on the need to incorporate a (eco)systemic perspective of integrated and multifaceted intensive care into the hospital environment and to other healthcare areas (...) an axis of healthcare, it proposes a incentivizing policy of the role of individuals, of the democratization of service management and of the comprehensive expansion of healthcare (...). The Healthcare System should contemplate the comprehensiveness of user/ 
citizen's needs, ensuring the responsibility of this system on the healthcare process as a whole (D4).

(...) principles and ways of operating within the group of relations between professionals, users and the various units and health services comprising the SUS (D6).

Segments allow us to distinguish the interrelationship of all the productive healthcare network's structural elements, meaning professionals/workers, the users, family members, the support services, financial and material resources, and other connections of the health system as a whole, thus being capable of favoring comprehensiveness in the ICU space/environment.

In order for interrelations to be established, the following segments demonstrate the diversity of elements that constitute comprehensiveness in healthcare actions in the ICU that need to be constructed based on:

(...) a systemic perspective of intensive care (...) as a strategy of interference in the healthcare production process, taking into account that when social subjects are mobilized, they are able to transform realities, and transform themselves in the process (D4).

(...) planning, decision-making mechanisms, implementation and evaluation strategies, and above all how such processes take place, they should all converge for the construction of committed and united changes within healthcare production (D6).

(...) integration with all the healthcare processes and coordination with the organizational processes (D7).

With respect to the health production process, what predominates is interrelationships between all the elements that integrate nursing care management processes in the ICU.

\section{INTEGRATING PROCESSES AND PROMOTERS OF HUMANIZATION}

To analyze nursing care management in the ICU, as an integration process and promoter of humanization, several aspects are necessary:

Appreciation of subjective and social dimensions in all practices of healthcare and management, strengthening/stimulating processes for integration and promoting commitment/accountability (D3).

Intensive therapy requires that we discuss the care to critical or potentially critical patients at all assistive moments and spaces (D4).

These segments, in addition to defending that healthcare practices are rooted in the specificities and singularities of the users, also highlights the need for understanding the demands of the health-disease process to promote comprehensive and humanized healthcare.

In this sense, it is necessary that nursing care management in the ICU is interconnected to the ethical values of the profession, such as human dignity, responsibility, sensitivity and solidarity, as expressed in the segment:

(...) offering quality care, articulating technological advances with enthusiasm, having improved healthcare environments and professional working conditions (...) processes committed to bealth production (D4).
The interrelationship of these processes enables management configuration and provides the construction of strategies capable of subsidizing the organization and implementing nursing care actions in the ICU:

(...) actions which ensure workers' participation in the discussion and decision-making processes, thus recognizing, valuing and strengthening their commitment to the healthcare production process and their professional growth (D3).

Interdisciplinary and transdisciplinary care required to comprehensively meet the demands of critical/potentially critical patients should minimally comprise the effective and shared participation of professionals (D4).

\section{DISCUSSION}

The study results show that comprehensiveness in nursing care management in the ICU presents some challenges regarding the complementarity of broad and inclusive actions. It is observed that the health professionals involved in providing such care are faced with an increasing degree of technical, scientific, affective, integrative and social demands towards health promotion and maintenance in critical and emergency situations. However, the professional relationship in the ICU setting in many health institutions also expressed an organization of mechanical, hierarchical and fragmented work, and has been the point of instability between authors who envision a more flexible, dynamic and cooperative relationship based on dialogue and collective construction, seeking to satisfy the interests and needs of all who are part of that context ${ }^{(6,17-19)}$. The need to change the way of thinking, acting and organizing work should be perceived based on studies and current legislation for ICUs.

These findings lead us to configure nursing work organization in the ICU in order to consider its actions/healthcare activities for critical users not only in treating diseases, but also focusing on caring for the human being holistically, creating opportunities to meet their demands for prevention, promotion, diagnosis and rehabilitation in their multiple dimensions ${ }^{(8)}$.

The systemic and integrated view indicated in documents 4, 6 and 7, allows us to understand the need for innovating the form of organizing and implementing the work process in health. Thus, it is crucial to consider that the biomedical model no longer attains accommodating user needs and what it takes for this to be seen in its entirety, in solidarity, is to converge all efforts to achieve results with regard to healthcare production. This new way of organizing the work process is supported by studies ${ }^{(4-6,8,19-22)}$ which indicate from their findings that we need to understand the healthcare needs better, with the purpose of developing actions for comprehensive healthcare which consider the diversity, the instabilities and complexity of users' demands.

We emphasize that this way of thinking represents challenges for achieving comprehensiveness, demonstrating that there is a need for interaction between all healthcare processes and linking them with organizational processes. Moreover, it is important to consider that comprehensive healthcare is connected to the other dimensions, such as 
the $\mathrm{D} 7$ segment. This necessary interrelation highlighted in this study is anchored in other studies ${ }^{(18,20-22)}$ that consider integrity as a guiding principle of healthcare practices, able to drive the management process from the complementarity and interdependence of healthcare actions. Moreover, it is necessary to understand the interrelationships that allow for organizing the work and for producing healthcare because the practices depend on this interactive/relational dynamic among professionals/workers and users, combined with organizational/managerial processes.

Nursing practice inserted in the context of health practices faces the daily challenge of producing new logistics of work organization, by setting up actions guided by comprehensiveness, and thereby redefining activities and knowledge that incorporate subjectivity and singularity into healthcare production ${ }^{(22)}$. For the authors, comprehensiveness in the training of professionals/nurses is the premise for the reorganization of practices, since it determines and guides the acquisition of skills and abilities for professional practice.

The professional/nurse acting as a coordinator of care actions is related to the responsibility of organizing work and nursing/health management practices ${ }^{(23)}$. The American Nurses Credentialing Center, responsible for the designation of the Magnet Hospital status, argues that healthcare excellence can only be achieved and maintained if the nurses have influence and decision-making power over nursing practic$\mathrm{es}^{(24)}$. Thus, excellence can be considered as a model with the potential to promote multidisciplinary interrelationships and to create an organizational culture that allows innovation and ensures greater quality and safety in healthcare actions ${ }^{(25)}$.

In a practical scenario, it is possible to observe a structural self-organization of ICUs, both in their environmental composition and in the area of human resources, formed by specialized multidisciplinary teams that are integrated with technological advances which enable them to improve the quality and safety of care. However, the quality of care is not only guaranteed by the qualification of its professionals, but also by their quantification for the development of legally planned activities ${ }^{(8,22)}$.

In this approach, health humanization proposals also involve rethinking the process of training health professionals, still predominantly focused on the technical, rational and individualized learning with attempts that are often lacking in critical exercise, creativity and sensitivity. This implies a critical approach, which allows us to understand the process beyond its technical, technological and organizational components, primarily involving their political and philosophical dimensions which imprint an ethical, supportive and humane significance on healthcare actions ${ }^{(18-22)}$.

On the other hand, studies ${ }^{(17-22,26)}$ have identified that work in a multi-professional team is a guiding assumption for self-organization of the work process in healthcare services. Thus, from a greater interaction between the professionals and the actions that they develop, it is possible to seek changes in the ways of acting/practices regarding factors that interfere with healthcare production.

Adoption of a transdisciplinary approach in the humanization process needs to take into account the complementary and convergent principles that shape nursing care management in the ICU. Along the same concept, other studies ${ }^{(17-18,20,22,26)}$ consider that it is necessary to understand the work team in an interdisciplinary manner, respecting forms of expression and autonomy resulting from relations that are in a permanent construction process.

In the ICU space/environment, teamwork is implicated in sharing the planning, a collective work organization sustained in the interrelationships that are processed through cooperation, collaboration, information exchange, amongst other knowledge, skills and competencies that enhance the actions in healthcare production ${ }^{(8,17-22,26)}$.

In this perspective, it is important to recognize and value the knowledge constructed by health professionals in their everyday work ${ }^{(6,8,17-19,21)}$. Thus, it is understood that there are no isolated actions, but rather interconnected actions that build, interweave and complement in a relational, energetic, informational and/or materialistic manner among living systems and their ecosystems ${ }^{(5-8)}$.

\section{CONCLUSION}

By rethinking the management model of nursing care in the ICU to be consistent with public policies and with a focus on comprehensiveness and humanization, it considers the importance of redeeming the peculiarities and complexities of users, who are unique human beings and need to have their multi-dimensionalities met. A management model based on ecosystemic thinking and emerging theory leads to an understanding of the health-disease-care process as a whole, capable of expanding the possibilities for nursing actions in the face of instability, fluctuations and divergences that occur in the ICU environment, occurring in an effective, safe and quality manner for healthcare production.

This management model being anchored in the context of space/environment, considers all the elements that participate in it - physical, human and technological resources, legislation, protocols, clinical guidelines - and leads nurses to take ownership of knowledge capable of providing understanding of the interrelationships and influences of each of the elements that are interconnected, and participate, as a whole, in the health-disease-care process. In this sense, the theoretical-philosophical and organizational applications present in public policy documents provide the basic conditions of organization, structure and management by establishing compliance to rules and regulations that guide the ICU's operation in order for these units to operate in a systemic way, with protocols and clinical guidelines in accordance with current legislation, and all for the benefit of users and healthcare workers.

Given these matters, nursing care management in the ICU has some challenges regarding the complementarity of actions being conducted in a broad and inclusive manner. Therefore, we have perceived the need to produce creative and innovative management actions which are able to integrate practices with more flexible, dynamic and cooperative processes based on dialogue and collective construction, as well as more favorable results in the production of healthcare which include the user and the family in this 
process. In order for this process to happen in individual and collective environments according to the needs of users, effective public policies need to be established including health promotion, disease prevention, diagnosis, treatment and rehabilitation. For this, it is necessary to implement an ecosystemic approach into the management process, linking and interconnecting the technical, organizational, technological and humanizing dimensions that compose the network which configures the comprehensiveness and humanization of nursing care management in the ICU.

Thus, comprehensiveness and humanization of nursing care management in the ICU based on ecosystemic thinking challenges the professional/nurse to rethink their professional attitude, making it essential to create a communicative, interactive and relational space for sharing and living together, thereby narrowing the emotional bond between users, families and teams.

We reaffirm that understanding the relationships of the elements that structure nursing care management in the ICU is capable of producing benefits for forming new public healthcare policies, providing a reorganization of the existing policies, promote integrity and humanization of nursing/health care and possessing strong potential for transforming health practices.

\section{RESUMO}

Objetivo: Identificar os elementos capazes de promover a integralidade e a humanização na gestão do cuidado de enfermagem na Unidade de Terapia Intensiva, com enfoque ecossistêmico. Método: Pesquisa documental, de natureza qualitativa. Para a análise dos dados utilizou-se do método da análise documental. Resultados: Foram identificadas quatro categorias preestabelecidas - Dimensões: Técnica; Organizacional; Tecnológica e Humanizadora. Os dados resultantes das duas subcategorias que integraram a categoria Dimensão Humanizadora, Integralidade nas ações do cuidado e Processos integradores e promotores de humanização, trazem implicações e desafios nos modos de gerir os processos de trabalho em saúde, o que possibilita transformações organizacionais, estruturais e gerenciais na produção do cuidado. Conclusão: Considera-se que na gestão do cuidado de enfermagem todos os elementos estruturantes, com enfoque nas necessidades dos usuários, devem estar em consonância com as políticas públicas e os princípios da integralidade e da humanização e possuir forte potencial para a transformação das práticas em saúde.

\section{DESCRITORES}

Gestão em Saúde; Cuidados de Enfermagem; Humanização da Assistência; Unidade de Terapia Intensiva; Integralidade em Saúde; Políticas Públicas de Saúde.

\section{RESUMEN}

Objetivo: Identificar los elementos capaces de promover la integralidad y la humanización en la gestión del cuidado de enfermería en la Unidad de Cuidados Intensivos, con enfoque ecosistémico. Método: Investigación documental, de naturaleza cualitativa. Para el análisis de los datos se utilizó el método de análisis documental. Resultados: Fueron identificadas cuatro categorías prestablecidas Dimensiones: Técnica; Organizacional; Tecnológica y Humanizadora. Los datos resultantes de las dos subcategorías que integraron la categoría Dimensión Humanizadora, Integralidad en las acciones del cuidado y Procesos integradores y promotores de humanización, traen implicaciones y retos en los modos de gestionar los procesos laborales sanitarios, lo que posibilita transformaciones organizacionales, estructurales y de gestión en la producción del cuidado. Conclusión: Se considera que en la gestión del cuidado de enfermería todos los elementos estructuradores, con enfoque en las necesidades de los usuarios, deben estar en consonancia con las políticas públicas y los principios de la integralidad y la humanización y tener fuerte potencial para la trasformación de las prácticas sanitarias.

\section{DESCRIPTORES}

Gestión en Salud; Atención de Enfermería; Humanización de la Atención; Unidad de Cuidados Intensivos; Integralidad en Salud; Políticas Públicas de Salud.

\section{REFERENCES}

1. Brasil. Ministério da Saúde. Portaria n. 2.446, de 11 de novembro de 2014. Redefine a Política Nacional de Promoção da Saúde (PNPS) [Internet]. Brasília; 2014 [citado 2015 out. 12]. Disponível em: http://bvsms.saude.gov.br/bvs/saudelegis/gm/2014/prt2446_11_11_2014. html

2. Montenegro LC, Penna CMM, Brito MJM. Comprehensive care from the perspective of health care workers from Belo Horizonte. Rev Esc Enferm USP [Internet]. 2010 [cited 2015 Oct 03];44(3):644-51. Available from: http://www.scielo.br/pdf/reeusp/v44n3/en_14.pdf

3. Lima MM, Kloh D, Canever BP, Reibnitz KS, Amestoy SC, Prado ML. Integralidade na formação do enfermeiro: possibilidades de aproximação com os pensamentos de Freire. Saúde Transform Soc. 2013;4(1):3-8.

4. Oliveira R, Maruyama SAT. Princípio da integralidade numa UTI pública: espaço e relações entre profissionais de saúde e usuários. Rev Eletr Enferm [Internet]. 2009 [citado 2015 out. 15];11(2):375-82. Disponível em: https://www.fen.ufg.br/fen_revista/v11/n2/v11n2a19.htm

5. Zamberlan C, Calvetti A, Svaldi JSD, Siqueira HCH. Ambiente, saúde e enfermagem no contexto ecossistêmico. Rev Bras Enferm. 2013;66(4):603-6.

6. Svaldi JSD, Siqueira HCH. Ambiente hospitalar saudável e sustentável na perspectiva ecossistêmica: contribuições da enfermagem. Esc Anna Nery. 2010;14(3):599-604.

7. Zamberlan C, Calvetti A, Deisvaldi J, Siqueira HCH. Calidad de vida, salud y enfermería en la perspectiva ecosistémica. Enferm Global [Internet]. 2010 [citado 2015 out. 20];9(3). Disponible en: http://revistas.um.es/eglobal/article/view/110941 
8. Siqueira HCH, Medeiros AC, Zamberlan C. Configuração da gestão do cuidado de enfermagem na UTI. In: Sousa FGM; Dirce Stein Backes DS, organizadoras. Cuidado em enfermagem e saúde: diversidades e complexidades. Florianópolis: Papa Livro; 2015. p. 307-35.

9. Brasil. Ministério da Saúde. Portaria n. 1.071, de 4 de julho de 2005. Dispõe sobre a Política Nacional de Atenção ao Paciente Crítico [Internet]. Brasília; 2005 [citado 2015 out. 25]. Disponível em: http://bvsms.saude.gov.br/bvs/saudelegis/gm/2005/prt1071_04_07_2005. $\mathrm{html}$

10. Brasil. Ministério da Saúde; Secretaria de Atenção à Saúde, Núcleo Técnico da Política Nacional de Humanização. Acolhimento nas práticas de produção de saúde. $2^{\text {a }}$ ed. Brasília: MS; 2010.

11. Celard A. A análise documental. In: Poupart J, Deslauriers J-P, Groulx L-H, Laperrière A, Mayer R, Pires AP, organizadores. A pesquisa qualitativa: enfoques epistemológicos e metodológicos. 2ª ed. Petrópolis: Vozes; 2010. p. 295-316.

12. Brasil. Ministério da Saúde. Portaria n. 3.432, de 12 de agosto de 1998. Estabelece Critérios de Classificação para as Unidades de Tratamento Intensivo [Internet]. Brasília; 1998 [citado 2015 out. 15]. Disponível em: http://bvsms.saude.gov.br/bvs/saudelegis/gm/1998/ prt3432_12_08_1998.html

13. Brasil. Ministério da Saúde; Agência Nacional de Vigilância Sanitária. RDC n. 50, de 21 de fevereiro de 2002. Dispõe sobre o Regulamento Técnico para planejamento, programação, elaboração e avaliação de projetos físicos de estabelecimentos assistenciais de saúde [Internet]. Brasília; 2002 [citado 2015 out. 20]. Disponível em: http://bvsms.saude.gov.br/bvs/saudelegis/anvisa/2002/res0050_21_02_2002.html

14. Brasil. Ministério da Saúde. Portaria n. 2.690, de 5 de novembro de 2009. Institui, no âmbito do Sistema Único de Saúde (SUS), a Política Nacional de Gestão de Tecnologias em Saúde [Internet]. Brasília; 2009 [citado 2015 out. 17]. Disponível em: http://bvsms.saude.gov.br/ bvs/saudelegis/gm/2009/prt2690_05_11_2009.html

15. Brasil. Ministério da Saúde; Agência Nacional de Vigilância Sanitária. Resolução RDC n. 7, de 24 de fevereiro de 2010. Dispõe sobre os requisitos mínimos para o funcionamento de Unidades de Terapia Intensiva e dá outras providências [Internet]. Brasília; 2010. [citado 2015 out. 28]. Disponível em: http://bvsms.saude.gov.br/bvs/saudelegis/anvisa/2010/res0007_24_02_2010.html

16. Brasil. Ministério da Saúde. Portaria n. 529, de $1^{\circ}$ de abril de 2013. Institui o Programa Nacional de Segurança do Paciente (PNSP) [Internet]. Brasília; 2013 [citado 2015 out. 15]. Disponível em: http://bvsms.saude.gov.br/bvs/saudelegis/gm/2013/prt0529_01_04_2013. html

17. Pirolo SM, Ferraz CA, Gomes R. The integrality of care and communicative actions in the cross- discipline practice in intensive care. Rev Esc Enferm USP [Internet]. 2011 [cited 2015 Oct 20];45(6):1391-7. Available from: http://www.scielo.br/pdf/reeusp/v45n6/en_v45n6a17.pdf

18. Medeiros AC, Pereira QLC, Siqueira HCH, Cecagno D, Moraes CL. Gestão participativa na educação permanente em saúde: olhar das enfermeiras. Rev Bras Enferm. 2010;63(1):38-42.

19. Camelo SHH. Professional competences of nurse to work in Intensive Care Units: an integrative review. Rev Latino Am Enfermagem. 2012;20(1):192-200.

20. Martins JJ, Albuquerque GL. A utilização de tecnologias relacionais como estratégia para humanização do processo de trabalho em saúde. Ciênc Cuid Saúde. 2007; 6(3):351-6.

21. Silva KL, Sena RR. Comprehensive health care: indications from the training of nurses. Rev Esc Enferm USP. 2008;42(1):48-56.

22. Backes MTS, Erdmann AL, Büscher A, Backes DS. O cuidado intensivo oferecido ao paciente no ambiente de Unidade de Terapia Intensiva. Esc Anna Nery Rev Enferm. 2012;16(4):689-96.

23. Chistovam BP, Porto IS, Oliveira DC. Nursing care management in hospital setting: the building of a construct. Rev Esc Enferm USP [internet]. 2012 [cited 2016 May 12]; 46(3):729-35. Available from: http://www.scielo.br/pdf/reeusp/v46n3/en_28.pdf

24. Barden AM, Griffin MT, Donahue M, Fitzpatrick JJ. Shared governance and empowerment in registered nurses working in a hospital setting. Nurs Adm Q. 2011;35(3):212-8.

25. Mcsherry R, Pearce P, Grimwood K, Mcsherry W. The pivotal role of nurse managers, leaders and educators in enabling excellence in nursing care. J Nurs Manag. 2012; 20(1):7-19.

26. Costa RKS, Enders BC, Menezes RMP. Trabalho em equipe de saúde: uma análise contextual. Ciênc Cuid Saúde. 2008;7(4):530-6. 